\title{
CMR assessment of myocardial mechanics and tissue characterization in patients treated with Anthracycline chemotherapy for acute myeloid leukaemia
}

\author{
Christopher A Miller ${ }^{1,2^{*}}$, Rahul Potluri ${ }^{1,2}$, Matthias Schmitt ${ }^{1,2}$ \\ From 15th Annual SCMR Scientific Sessions \\ Orlando, FL, USA. 2-5 February 2012
}

\section{Background}

Anthracycline-associated cardiomyopathy is a progressive, dose-dependent complication of Anthracycline chemotherapy. The period between Anthracycline therapy and onset of overt heart failure is often years, even decades, and as such Anthracyclines appear to initiate a myocardial injury that remains clinically silent for a substantial period of time. Left ventricular (LV) ejection fraction (EF) is often preserved during this latent period. A more sensitive marker of Anthracycline-associated myocardial injury would allow earlier diagnosis, hence potentially earlier initiation of cardioprotective therapy, and better prognostication.

We assessed the relationship between cumulative Anthracycline dose and myocardial function (global and regional) and myocardial fibrosis (focal and diffuse) in patients who had previously received Anthracycline chemotherapy for acute myeloid leukaemia (AML) with normal or near normal LV EF.

\section{Methods}

15 patients with a prior history of AML underwent 1.5T CMR (Avanto, Siemens). LV volumetric analysis was performed on SSFP images. Mitral inflow was assessed using phase-contrast velocity mapping. Spatial modulation of magnetization was performed on a mid-ventricular short-axis slice in order to assess peak systolic circumferential strain $(\varepsilon \mathrm{cc})$. T1 mapping was performed pre- and 10 -minutes post $0.15 \mathrm{mmol} / \mathrm{kg}$ gadoliniumDTPA using a modified look locker inversion recovery

University Hospital of South Manchester, Manchester, UK

Full list of author information is available at the end of the article sequence. $\Delta \mathrm{R} 1$ ratio $[(1 / \mathrm{T} 1$ myocardium post-contrast $)$ (1/T1myocardium pre-contrast $)] /[(1 /$ T1blood postcontrast) - (1/T1blood pre-contrast)] was used as a marker of diffuse myocardial fibrosis. Late gadolinium enhancement (LGE) images were acquired immediately after post-contrast T1 mapping.

\section{Results}

8 patients were male, mean age $49 \pm 17$ years. Mean time since AML diagnosis $7 \pm 4$ years. Mean cumulative Anthracycline dose $200 \pm 82 \mathrm{mg} / \mathrm{m} 2$ (range $75-362$ ). Mean body surface area-indexed end-diastolic volume (EDV) was $71 \pm 10 \mathrm{mls} / \mathrm{m} 2$, mean indexed end-systolic volume (ESV) was $30 \pm 5 \mathrm{mls} / \mathrm{m} 2$ and mean EF was $58 \pm 6 \%$ (range 51-70\%).

There was a significant correlation between cumulative Anthracycline dose and EDV (correlation coefficient 0.43, $\mathrm{p}=0.03)$ and ESV (0.43, $\mathrm{p}=0.03)$, but no correlation with EF. There were significant correlations between age and $\Delta \mathrm{R} 1$ ratio $(-0.57, \mathrm{p}=0.04)$, age and $\varepsilon \mathrm{cc}(0.59, \mathrm{p}=0.02)$ and age and E/A ratio $(-0.43, \mathrm{p}=0.02)$. There were also significant correlations between $\Delta \mathrm{R} 1$ ratio and $\mathrm{E} / \mathrm{A}$ ratio (0.58, $\mathrm{p}=0.003), \Delta \mathrm{R} 1$ ratio and indexed EDV $(0.44$, $\mathrm{p}=0.02)$ and $\Delta \mathrm{R} 1$ ratio and indexed ESV (0.41, $\mathrm{p}=0.04)$. However, there were no significant correlations between total Anthracycline dose and $\Delta \mathrm{R} 1$ ratio $(0.25, \mathrm{p}=0.19)$, total Anthracycline dose and $\varepsilon \mathrm{cc}(0.14, \mathrm{p}=0.49)$ or total Anthracycline dose and E/A ratio $(-0.04, \mathrm{p}=0.84)$. No patient had focal LGE.

\section{Conclusions}

In this small group of patients who received chemotherapy for AML a mean of 7 years previously, there was no 
association between cumulative Anthracycline dose and peak systolic circumferential strain or a marker of diffuse myocardial fibrosis.

\section{Funding}

Dr Miller was supported by a Doctoral Research Fellowship from the National Institute for Health Research, UK (NIHR-DRF-2010-03-98). Dr Schmitt was supported by Greater Manchester Comprehensive Local Research Network funding.

\section{Author details}

${ }^{1}$ University Hospital of South Manchester, Manchester, UK. ${ }^{2}$ University of Manchester, Manchester, UK.

Published: 1 February 2012

- Convenient online submission

- Thorough peer review

- No space constraints or color figure charges

- Immediate publication on acceptance

- Inclusion in PubMed, CAS, Scopus and Google Scholar

- Research which is freely available for redistribution 